\title{
Rancang Bangun SIA SMA Menggunakan Unified Process Berfokus pada Rapor Berbasis Kurikulum 2013
}

\author{
Defa Hanifta Putra. ${ }^{1}$, Satriyo Adhy. ${ }^{2}$ \\ Jurusan Ilmu Komputer/Informatika, Fakultas Sains Matematika, Universitas Diponegoro \\ Jalan Prof. H. Soedarto, SH. Tembalang Semarang 50275 \\ defahaniftaputra@gmail.com ${ }^{1}$, satriyo@undip.ac.id ${ }^{2}$
}

\begin{abstract}
Abstrak
Perkembangan teknologi semakin memudahkan manusia dalam mendapatkan, menyimpan, dan mengelola data serta informasi, salah satunya adalah adanya sistem informasi. Sistem informasi akademik merupakan varian dari sistem informasi yang ditujukan untuk menangani hal-hal akademis. Sesuai Peraturan Menteri Pendidikan dan Kebudayaan Republik Indonesia nomor 81A Tahun 2013, SMA merupakan salah satu satuan pendidikan yang menerapkan kurikulum 2013. Meskipun tidak semua SMA menerapkannya tetapi terhitung pada tahun 2015 ada beberapa SMA yang masih menerapkan kurikulum 2013 sebagai SMA percontohan atau untuk kepentingan evaluasi kurikulum itu sendiri. Adanya kendala-kendala dalam penerapan kurikulum 2013 maka dikerjakan penelitian mengenai rancang bangun sistem informasi akademik SMA berbasis kurikulum 2013 yang dikembangkan dengan metode pengembangan unified process. Sistem dikembangkan dengan ASP.NET 4.5, C\#, dan SQL Server Express 2012. Hasil akhir yang dapat dikeluarkan dari sistem yaitu rapor sesuai dengan kurikulum 2013.
\end{abstract}

Kata kunci : Sistem informasi, SIA, SMA, Web, Unified Process, kurikulum 2013, ASP.NET.

\section{Pendahuluan}

Menurut Undang-Undang Nomor 20 Tahun 2003 tentang Sistem Pendidikan Nasional, kurikulum adalah seperangkat rencana dan pengaturan mengenai tujuan, isi, dan bahan pelajaran serta cara yang digunakan sebagai pedoman penyelenggaraan kegiatan pembelajaran untuk mencapai tujuan pendidikan tertentu. Berdasarkan Peraturan Menteri Pendidikan dan Kebudayaan nomor 69 tahun 2013, kurikulum 2013 dikembangkan atas teori "pendidikan berdasarkan standar" (standardbased education), dan teori kurikulum berbasis kompetensi (competency-based curriculum). Penilaian dan penyusunan rapor menggunakan kurikulum 2013 terdapat tiga aspek yaitu pengetahuan (KI-3), keterampilan (KI-4), sikap spriritual dan sosial (KI-1 dan KI2).Terdapat konversi nilai dari angka ke skala 1 sampai dengan 4 untuk nilai pengetahuan dan keterampilan. Sedangkan untuk nilai sikap terdapat konversi nilai dari angka ke SB, B, dan C.

Pada penelitian ini, SMA yang dijadikan studi kasus telah memiliki template Excel yang dibagikan kepada semua guru mata pelajaran sebagai acuan penilaian. Penilaian yang diberikan guru mata pelajaran merupakan dasar dalam pembuatan rapor kurikulum 2013. Namun staf kurikulum masih mendata ulang kembali nilai yang disetorkan oleh guru mata pelajaran dan wali kelas dalam menyusun rapor. Guru mata pelajaran dan wali kelas tidak memiliki akses yang memungkinkan pemasukan nilai dilakukan secara mandiri.

Berdasarkan kendala-kendala yang ada dalam pelaksanaan kurikulum 2013 maka dipandang perlu dilakukan penelitian mengenai rancang bangun sistem informasi akademik SMA berbasis kurikulum 2013 yang dikembangkan dengan metode pengembangan unified process. Tujuan dari penelitian ini adalah untuk menghasilkan sistem informasi akademik SMA sesuai dengan kurikulum 2013.

\section{Landasan Teori}

Kurikulum 2013 memiliki beberapa ketentuan. Pada kurikulum 2013 terdapat empat kompetensi inti, yaitu :

1. Kompetensi Inti-1 (KI-1) untuk kompetensi inti sikap spiritual.

2. Kompetensi Inti-2 (KI-2) untuk kompetensi inti sikap sosial.

3. Kompetensi Inti-3 (KI-3) untuk kompetensi inti pengetahuan. 
4. Kompetensi Inti-4 (KI-4) untuk kompetensi inti keterampilan.

Kompetensi inti juga dijadikan acuan dalam penilaian yang dibagi menjadi tiga kategori yaitu meliputi nilai pengetahuan, nilai keterampilan, dan nilai sikap. Mata pelajaran pada kurikulum 2013 dibagi menjadi empat yang meliputi : kelompok A, kelompok B, kelompok $\mathrm{C}$, dan kelompok lintas minat. Penilaian setiap mata pelajaran meliputi kompetensi pengetahuan, kompetensi keterampilan, dan kompetensi sikap. Kompetensi pengetahuan dan kompetensi keterampilan menggunakan skala 14, sedangkan kompetensi sikap menggunakan skala Sangat Baik (SB), Baik (B), Cukup (C), dan Kurang (K). Konversi nilai diilustrasikan pada Gambar 2.1 tetapi karena rentang penilaian belum ada standarnya maka rentang penilaian disesuaikan dengan sekolah yang menerapkan kurikulum.

\begin{tabular}{|c|c|c|c|}
\hline \multirow{2}{*}{ Predikat } & \multicolumn{3}{|c|}{ Nilai Kompetensi } \\
\cline { 2 - 3 } & Pengetahuan & Keterampilan & Sikap \\
\hline A & 4 & 4 & \multirow{2}{*}{ SB } \\
\hline A- & 3.66 & 3.66 & \\
\hline B+ & 3.33 & 3.33 & \multirow{2}{*}{ B } \\
\hline B & 3 & 3 & \\
\hline B- & 2.66 & 2.66 & \multirow{2}{*}{ C } \\
\hline C+ & 2.33 & 2.33 & \\
\hline C & 2 & 2 & \multirow{2}{*}{} \\
\hline C- & 1.66 & 1.66 \\
\hline
\end{tabular}

Gambar 1. Tabel Konversi Kompetensi

Pengetahuan, Keterampilan, dan Sikap(Menteri

Pendidikan dan Kebudayaan Republik

Indonesia, 2013)

Unified Process merupakan metode pengembangan perangkat lunak yang bersifat iteratif (Larman, 2001). Model pengembangan unified process memiliki empat fase dan lima workflow seperti diilustrasikan pada Gambar 3.

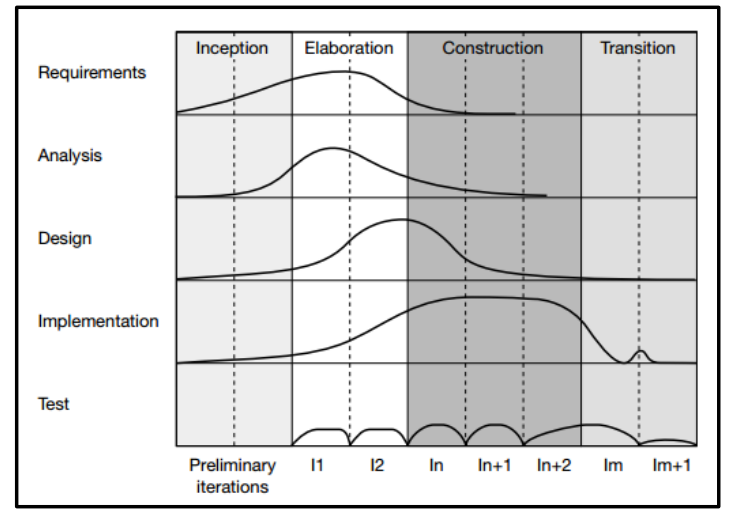

Gambar 3. Struktur Unified Process (Arlow \& Neustdat, 2002)

Berdasarkan Gambar 3, fase unified process dijelaskan seperti berikut :

a. Insepsi (inception)

Fase ini memiliki fokus dalam memahami lingkup proyek, tujuan, dan mendapatkan informasi yang cukup untuk memastikan apakah perangkat lunak layak dilanjutkan pengembangannya atau tidak. Yang ditekankan pada fase ini adalah workflow kebutuhan sistem dan analisis (Arlow \& Neustdat, 2002).

b. Elaborasi (elaboration)

Kebutuhan sistem yang sebelumnya telah didapat pada fase insepsi, diperbaiki pada fase elaborasi sehingga kebutuhan sistem menjadi lebih terstruktur dan mendekati valid. Core workflow yang intens dilakukan pada fase ini adalah kebutuhan sistem, analisis, dan desain (Arlow \& Neustdat, 2002).

c. Konstruksi (contruction)

Fokus dari fase ini adalah membangun dan melakukan pengujian perangkat lunak. Oleh karena itu, workflow yang intens dilakukan pada fase ini adalah implementasi. Perangkat lunak pada fase ini setidaknya telah mencapai versi beta dan siap dilakukan pengujian kepada pengguna (Arlow \& Neustdat, 2002).

d. Transisi (transition)

Kesalahan - kesalahan (cacat perangkat lunak) yang telah ditemukan pada fase sebelumnya telah diperbaiki. Pada fase ini, perangkat lunak di-deploy kepada pengguna (client).

Berdasarkan Gambar 2, core workflow dijelaskan seperti berikut : 
1. Kebutuhan (requirements)

Penangkapan kebutuhan yang disampaikan oleh klien adalah sangat penting.Secara umum, workflow kebutuhan adalah untuk menemukan apa yang dibutuhkan oleh klien.

2. Analisis (analysis)

Tujuannya adalah menganalisis dan memperbaiki kebutuhan-kebutuhan untuk memperoleh pemahaman yang lebih rinci terkait kebutuhan yang cenderung penting untuk pengembangan perangkat lunak (Scach, 2008). Namun begitu, kunci pentingnya adalah output dari kebutuhan sebisa mungkin dapat dipastikan telah dimengerti juga oleh klien.

3. Desain (Design)

Secara umum, tujuan dari workflow desain adalah untuk memperbaiki hasil dari analisis sampai bahan pengembangan perangkat lunak menjadi terstruktur hingga dapat diimplementasikan oleh programmer (Scach, 2008).

4. Implementasi (implementation)

Tujuannya adalah

untuk mengimplementasikan produk perangkat lunak target sesuai dengan menggunakan bahasa pemrograman tertentu (Scach, 2008).

5. Pengujian (testing)

Tujuannya adalah untuk mengevaluasi sistem sehingga kwalitas sistem dapat terjamin. Pengujian dilakukan untuk mendeteksi cacat (error)sehingga dapat dibuat laporan sehingga segera dilakukan perbaikan.

\section{Implementasi Unified Proces}

Penggunaan unified

process

memungkinkan pengembang untuk melakukan beberapa workflow dalam satu fase dan bisa jadi workflow yang telah dikerjakan diulang lagi pada fase berikutnya. Pada pengembangan sistem informasi akademik SMA, fase insepsi dilakukan workflow kebutuhan (requirements), analisis, desain, dan implementasi. Pada workflow kebutuhan dilakukan observasi prosedur manual yang telah berjalan di SMA. Pada workflow analisis dilakukan :

a. Observasi siapa saja yang menggunakan sistem (didapat pengguna meliputi siswa, guru, dan administrator). b. Meliputi apa saja hak dan tanggung jawab pengguna sistem.

c. Menganalisis kebutuhan lingkungan.

Kebutuhan lingkungan dari sisi client : seperangkat komputer yang terpasang browser dengan rekomendasi Mozilla Firefox versi 33 atau yang lebih baru. Kebutuhan lingkungan dari sisi server : hosting yang mampu menjalankan ASP.NET framework 4.5 dan SQL Server 2012.

d. Menganalisis kelas yang mewakili entitas.

Didapat class diagram yang mewakili entitas seperti diilustrasikan pada Gambar 4.

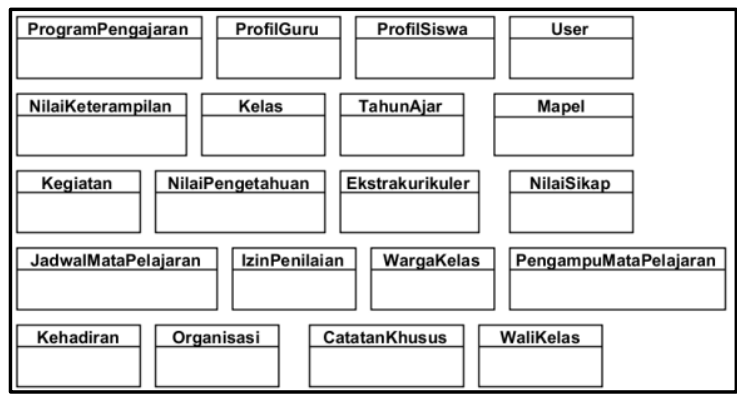

Gambar 4. Class Diagram (mewakili entitas)

Fase Insepsi

Pada fase insepsi, pada workflow desain dilakukan perancangan arsitektur awal (clientserver) serta merancang sketsa antarmuka untuk MasterPage dan halaman login. Pada workflow implementasi, hanya dilakukan pengkodean sebatas tampilan (HTML, ASP, Ajax, JQuery, dan JavaScript) belum dilakukan pengkodean logika. Workflow pengujian belum dilakukan pada fase insepsi.

Pada fase elaborasi, dilakukan workflow kebutuhan sistem, analisis, desain, implementasi, dan pengujian. Pada workflow kebutuhan sistem, dilakukan :

a. Memperoleh kebutuhan fungsional dan nonfungsional sistem.

b. Memodelkan use case yang meliputi aktor dan use case.

c. Pembuatan diagram use case, seperti diilustrasikan pada Gambar 5. 


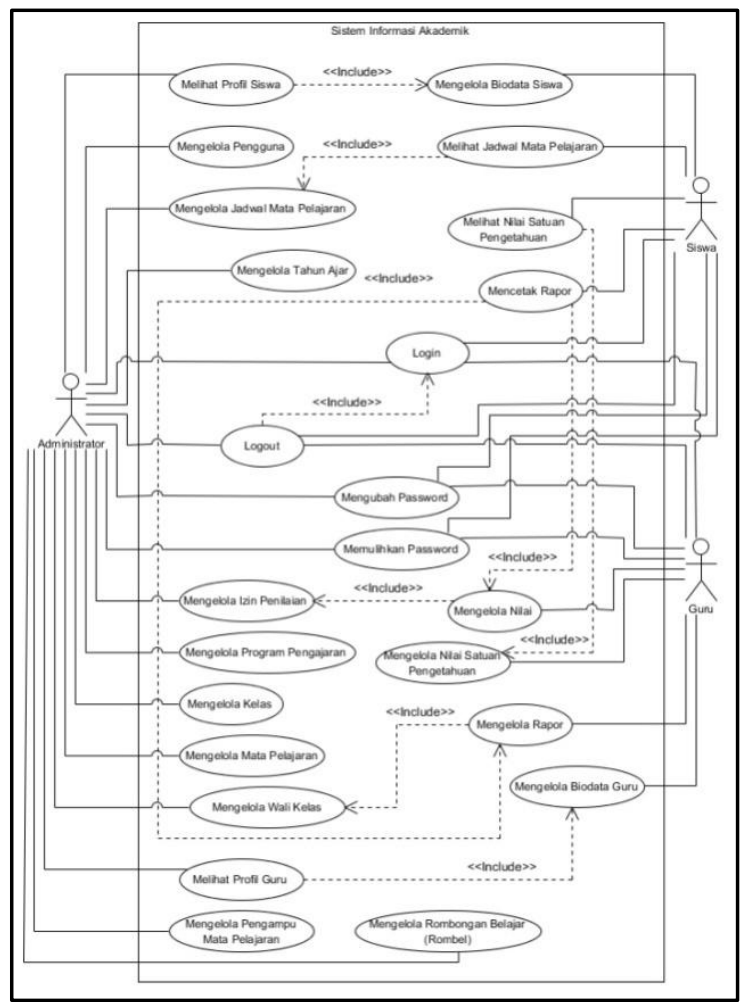

Gambar 5. Diagram Use Case Sistem

\section{d. Pembuatan use case detail.}

Setelah workflow kebutuhan sistem, pada fase elaborasi dilakukan workflow analisis. Pada workflow analisis dilakukan :

a. Membuat realisasi use case yang dituangkan dalam analysis class diagram. Dalam artikel ini diwakilkan oleh use case mengelola nilai seperti diilustrasikan pada Gambar 6.

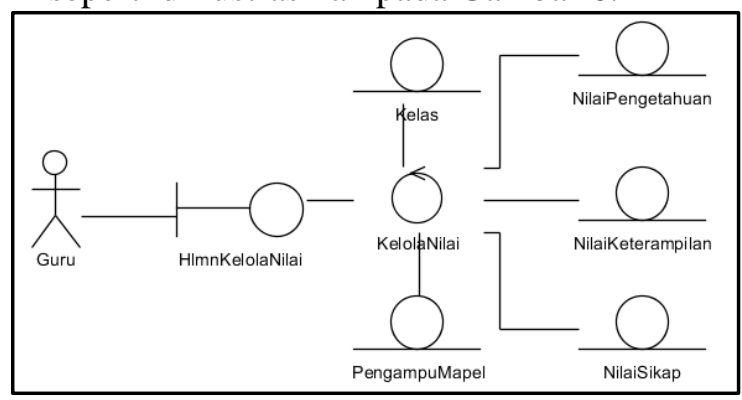

Gambar 6. Analysis Class Diagram Mengelola Nilai

b. Membuat sequence diagram. Dalam artikel ini diwakilkan oleh use case mengelola nilai seperti diilustrasikan pada Gambar 7 yaitu untuk aksi memberi penilaian.

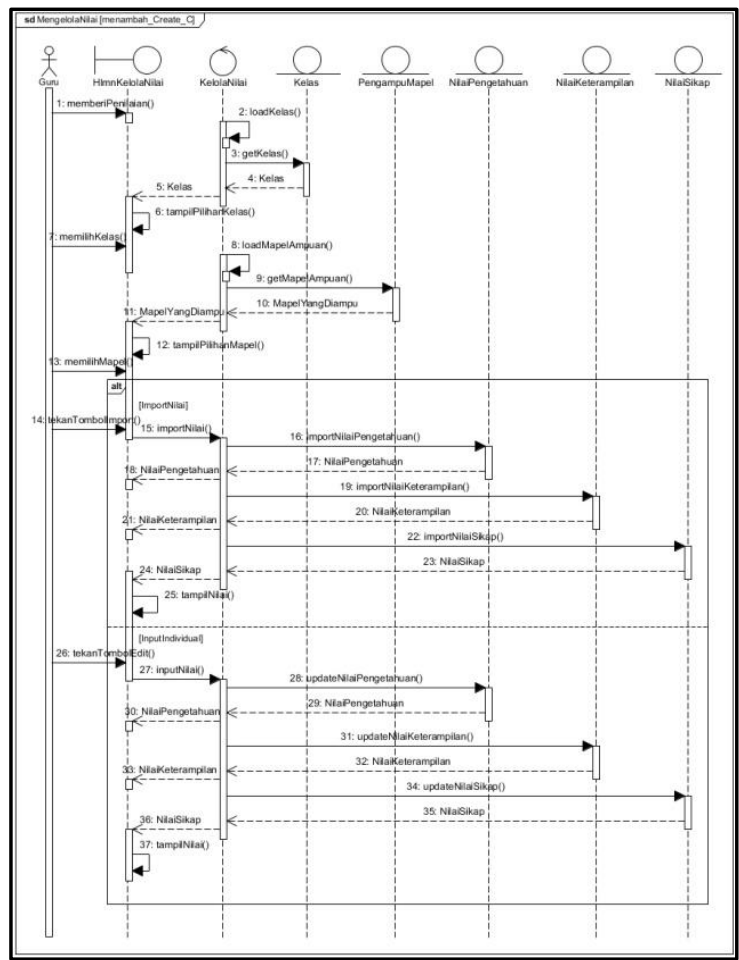

Gambar 7. Sequence Diagram Mengelola Nilai (memberi penilaian)

Setelah workflow analisis fase elaborasi, dilanjutkan dengan workflow desain. Pada workflow desain fase insepsi dilakukan :

a. Membuat arsitektur sistem (client-server) yang lebih rinci, seperti diilustrasikan pada Gambar 8.

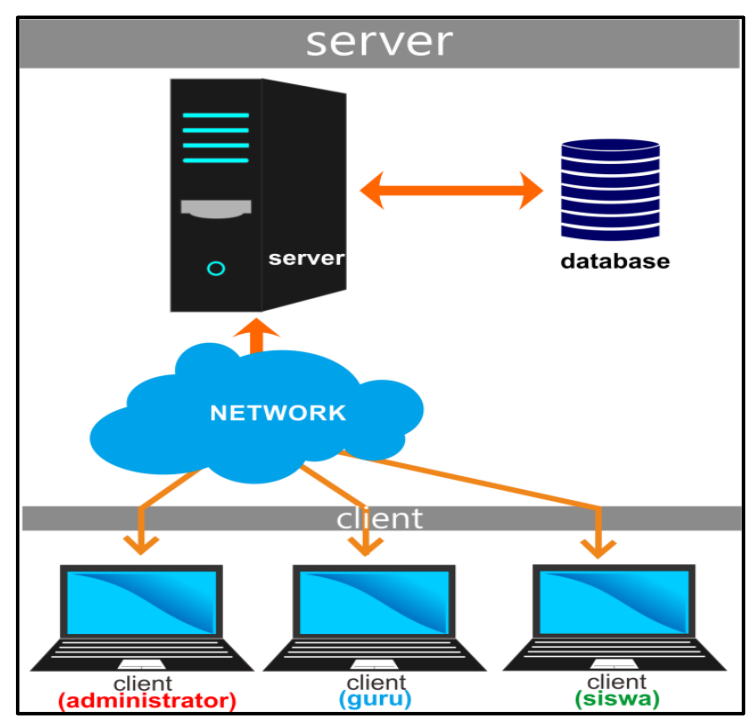

Gambar 8. Arsitektur Sistem Informasi Akademik 
b. Merancang basis data.

Pada perancangan basis data merupakan bagian dari workflow desain. Pada peelitian ini perancangan basis data wakili dengan data mapping yang diilustrasikan pada Gambar 9.

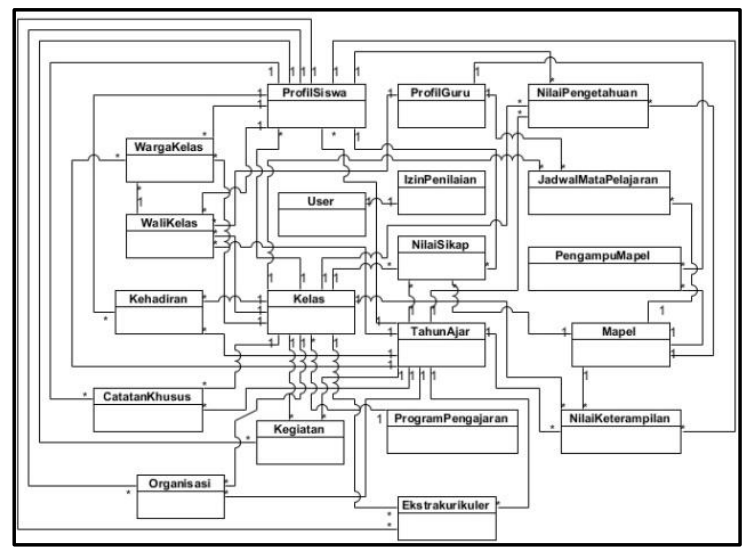

Gambar 9. Data Mapping Sistem Informasi Akademik

c. Membuat sketsa antarmuka sistem.

Antarmuka dirancang terhadap semua use case yaitu dengan membuat sketsa yang merupakan acuan dalam pembuatan antarmuka sistem.

Setelah workflow desain fase elaborasi, dilanjutkan workflow implementasi. Pada workflow ini implementasi kode program dilakukan hanya sebatas pada use case login. Workflow pengujian fase elaborasi dilakukan terhadap use case login.

Setelah fase elaborasi lantas masuk ke fase konstruksi. Pada fase ini fokus kegiatan adalah menulis kode program dan melakukan pengujian. Pada artikel ini, implementasi diwakili oleh use case mengelola nilai. Antarmuka sistem diilustrasikan pada Gambar 10. Rapor dengan standar kurikulum 2013 diilustrasikan pada Gambar 11.

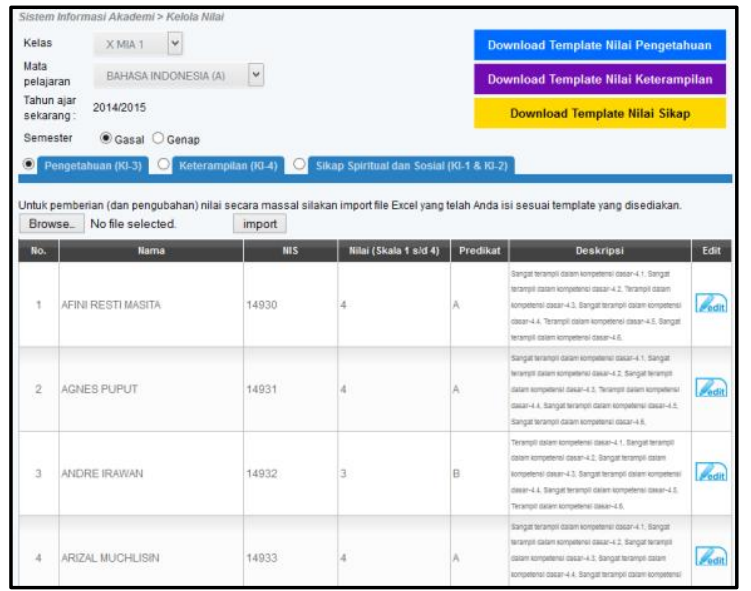

Gambar 14. Antarmuka Halaman Kelola Nilai

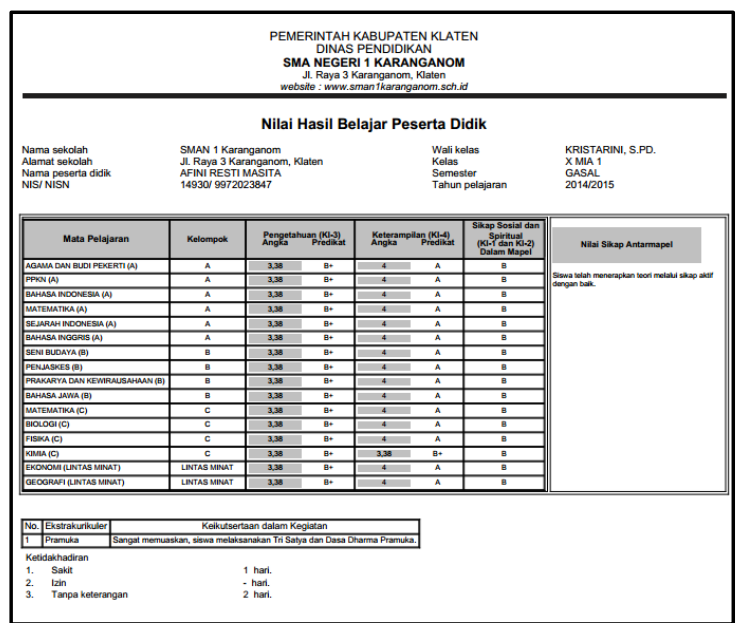

Gambar 11. Rapor dengan Kurikulum 2013 (halaman 1)

Setelah implementasi, workflow yang dilakukan pada fase konstruksi adalah pengujian. Pengujian dilakukan secara blackbox untuk mengidentifikasi bahwa fungionalitas sistem telah berjalan sebagaimana mestinya.

Setelah fase konstruksi lantas masuk ke fase transisi. Pada fase transisi, sistem diserahkan kepada pemangku kepentingan dalam hal ini SMA yang bersangkutan. Jika masih terjadi errormaka diperbaiki kembali dan diserahkan lagi ke pemangku kepentingan.

\section{Penutup}

Kesimpulan yang dapat diambil dari penelitian ini adalah berhasil dibangun Sistem Informasi Akademik berbasis kurikulum 2013yang dikembangkan dengan metode pengembangan unified process. Sistem berhasil 
dikembangkan dengan ASP.NET 4.5, C\#, dan SQL Server 2012.

\section{Referensi}

[1]. Arlow, J. \& Neustdat, I., 2002. UML and The Unified Process Practical ObjectOriented Analysis \& Design. London, Great Britain: Addison-Wesley.

[2]. Ladjamudin, A.-B.b., 2005. Analisis dan Desain Sistem Informasi. Yogyakarta: Penerbit Graha Ilmu.

[3]. Larman, C., 2001. Applying UML and Patterns : An Introduction to ObjectOriented Analysis and Design and the
Unified Process. 2nd ed. Upper Saddle River, New Jersey: Prentice Hall.

[4]. Menteri Pendidikan dan Kebudayaan Republik Indonesia, 2013. Peraturan Menteri Pendidikan dan Kebudayaan Republik Indonesia Nomor 81A Tahun 2013 Tentang Implementasi Kurikulum. Salinan Lampiran Peraturan Menteri. Jakarta: Kementerian Pendidikan dan Kebudayaan KEMENDIKBUD.

[5]. Scach, S.R., 2008. Object-Oriented Software Engineering. New York: McGraw-Hill. 